\title{
The Role of an Instructor's Asynchronous Feedback in Promoting Students' Interaction and Text Revisions
}

\author{
Mohammed Abdullah Alharbi ${ }^{1}$ \\ ${ }^{1}$ Department of English, College of Education, Majmaah University, Majmaah, Saudi Arabia \\ Correspondence: Mohammed Abdullah Alharbi, Department of English, College of Education, Majmaah \\ University, Majmaah, Saudi Arabia. E-mail: maalharbi@mu.edu.saｈttp://orcid.org/0000-0001-5548-2340
}

\author{
Received: January 15, 2019 Accepted: February 14, 2019 Online Published: April 6, 2019 \\ doi:10.5539/ijel.v9n3p23 URL: https://doi.org/10.5539/ijel.v9n3p23
}

\begin{abstract}
This study focused on teacher asynchronous feedback and how it engaged 15 English as Foreign language (EFL) learners in revising their writing. The data was collected from (1) the teacher's feedback, (2) students' responses and, (3) students' drafts of writing. The data analysis showed that the teacher provided a number of 832 items of feedback which were categorized into "question" as the most dominating category, followed by "statement", "suggestion", "directive" and "correction". Three hundred and eighty (380;46\%) of the feedback items were direct, while 452 (54\%) were indirect. The feedback focused on content, organization, vocabulary, grammar, mechanics and more general/not specific comments. Teacher's feedback (1) engaged the learners in text revisions (overall=1102 comments), (2) stimulated their responses (overall=1032 comments) and (3) extended their online asynchronous interactions. Of the total amount of text revisions (1102), 362 (33\%) were made based on the teacher's direct feedback, and 427 (38\%) of them were based on the teacher's indirect feedback, while $313(29 \%)$ were based on peers' and self-corrections. The learners revised their writing in terms of content, organization, vocabulary, grammar and mechanics. The findings have implications for teacher interactive feedback practices in writing and the role of asynchronous tools in facilitating such practices.
\end{abstract}

Keywords: teacher feedback, learners' interactions, EFL writing, text revisions

\section{Introduction}

Teacher feedback has been recognized as one of the important pedagogical tools to learners of English as a second/foreign language (ESL/EFL), in particular with respect to their writing (Ferris, 1997; Leki, 1991; Zamel, 1985). It is necessary at every stage of the writing process, especially in the revision stage, since learners need to revise their writing from a reader's perspective (Harran, 2011). Teacher feedback on ESL/EFL writing has also been supported by increasing applications of Vygotsky and Cole's (1978) sociocultural theory to ESL/EFL learning and writing in particular. According to this theory, the importance of teacher feedback on writing comes from the role of teachers in mediating learners' cognitive development and in facilitating their writing through scaffolds (Bitchener \& Ferris, 2012; Lee, 2014). Hyland (2003) asserts teacher feedback practices are better informed by such theories since they improve understanding of learners' cognitive processes when responding to feedback.

Research has documented the various patterns and characteristics of teacher feedback on ESL/EFL writing by analyzing its functions and foci (Conrad \& Goldstein, 1999; Ferris, 1997; Treglia, 2009). Researchers have also debated what constitutes effective teacher feedback and what areas of writing such feedback should target. Some researchers (Ferris \& Roberts, 2001; Hyland, 2003) argue that teachers should provide learners with indirect feedback, such as questions and suggestions, because these are more effective in engaging learners to revise their writing. On the other hand, other researchers (e.g., Conrad \& Goldstein, 1999; Williams, 2004) argue that teacher feedback should be direct to enable learners to better understand the issues in their writing through explicit instruction. Regardless of these arguments, previous research reveals that teacher feedback is an effective practice in writing instruction, and it helps ESL/EFL learners to revise and correct various issues in their texts (Kazemi, Abadikhah, \& Dehqan, 2018; Williams, 2004).

Despite the efficacy of teacher feedback, most practices in the EFL context tend to follow a traditional approach that focuses on the teacher as the provider of feedback while the students are passive learners. Such practices lack reciprocal interaction between the teacher and students. Some researchers (Lee, 2014; Yang, Badger, \& Yu, 
2006; Zhao, 2010) argued, from the sociocultural theory, that teacher feedback practices should engage learners in dialogues or interactions that enable them to respond to the teacher, seek clarification in cases of misunderstood feedback, and negotiate intended meanings in writing. Moreover, while many studies focus on teacher feedback, scant research has specifically examined the role of such feedback in promoting learners' interactions about writing. Zhang and Hyland (2018) argued teacher feedback might not be effective if it does not promote learners' interactions; such interactions are still under researched. Finally, teacher feedback practices have also been facilitated by recent technological tools, such as blogs, wikis, and Google Docs (Ishtaiwa \& Aburezeq, 2015; Saeed \& Ghazali, 2017). Therefore, this study aimed to investigate teacher feedback and EFL university learners' engagement in paragraph writing using an asynchronous technology-here, a blog as a platform for teacher-learner discussions. Specifically, the study attempted to address the following research questions:

- What types of asynchronous feedback do instructors give on EFL learners' writing?

- In what ways does an instructor's asynchronous feedback promote EFL learners' interactions and revisions of their writing?

\section{Literature Review}

\subsection{Theoretical Perspectives on Teacher Feedback}

In this study, the investigation of teacher feedback is grounded on two main theoretical perspectives of ESL/EFL writing. The first is the cognitive view of ESL/EFL writing (Flower \& Hayes, 1981; Kroll, 1990). This perspective describes writing as a process that includes prewriting, writing, and revision (Flower \& Hayes, 1981). Teacher feedback is especially important in the revision stage when learners need to revise their writing accordingly (Ferris, 1997; Harran, 2011; Zamel, 1985).

The second theoretical approach is the sociocultural theory of Vygotsky and Cole (1978) and its subsequential theoretical developments (Aljaafreh \& Lantolf, 1994; Lantolf, 2000). The most important aspect of this theory is the learners' zone of proximal development (ZPD), which is hypothesized to occur as a result of mediated interactions between teachers and learners or even between learners (Aljaafreh \& Lantolf, 1994; Nassaji \& Swain, 2000). Expert scaffolding refers to assistance provided by the teacher to learners in solving task-oriented problems within the ZPD (Wood, Bruner, \& Ross, 1976), which fosters L2 learning development. Teacher feedback, considered a kind of scaffold (Aljaafreh \& Lantolf, 1994; Lantolf, 2000), is useful if it is provided to learners appropriately and in an interactive manner (Bitchener \& Ferris, 2012; Lee, 2014).

Both theories complement each other in better exploring teacher feedback practices. Whereas the cognitive theory emphasizes cognitive efforts made through written feedback in explaining the types of issues that can arise in students' writing, the sociocultural theory emphasizes the role of assistance given by more capable individuals (teachers) to less capable individuals (learners) to understand language issues and write better.

\subsection{Previous Research on Patterns of Teacher Feedback}

Research has identified patterns of instructor feedback to establish what constitutes effective feedback on writing. For instance, Conrad and Goldstein (1999) identified the following types of feedback: directive to revise, directive to make choices in revising, directive not to revise, encouragement, praise, evaluation, revised location, explanation of the need for revision, identification of areas that need revisions, offers of help, request for clarification, and mitigation of criticism.

Ferris (1997) categorizes written teacher feedback into questions, statements, requests or imperatives, positive comments, and giving information. Treglia (2009) reported that most feedback came in the form of requests, followed by providing information and praise, whereas the least frequently used types of feedback were clarifications and suggestions. In a study by Alvarez, Espasa, and Guasch (2012), most teacher feedback consisted of suggestions and corrections, while other types, such as clarification, opinions or evaluation, and questions, were implemented least frequently. According to Kazemi et al. (2018), the most frequent teacher feedback was directive, whereas the least frequently used feedback was through giving a summary.

Some of these studies also attempted to identify the most effective patterns of teacher feedback. For instance, Ferris's study (1997) indicated that questions led to fairly substantive changes compared to requests for information. The latter technique was taken seriously by students in revising their texts. Keh (1990) found that teacher feedback questions encouraged interactive dialogues between teacher and students and led to text revisions.

From the existing literature, it is evident that most previous research has focused on the various types of teacher 
feedback. However, mere identification of patterns of feedback might not be effective. Therefore, it is important to consider explicitness versus implicitness or directness versus indirectness of teacher feedback. The nature of such feedback will help us to better understand not only the efficacy of teacher feedback but also how learners respond to various types of feedback and revise their writing accordingly. As such, one area of research focuses specifically on direct and indirect corrective feedback. Direct feedback (Lalande, 1982; Semke, 1984) refers to a teacher's insertion or removal of a given linguistic form and additional explanations for this. On the other hand, indirect corrective feedback (Chandler, 2000; Ferris, 1997) points to a given error in an indirect way, such as through coding the error, asking a question, underlining or circling the error, and so forth.

Bitchener and Knoch (2008) found that direct corrections only, direct corrections with oral explanations, and direct corrections with written explanations were effective for students' revision of writing. Alvarez et al. (2012) suggested that suggestions and questions were more useful than direct corrections in enhancing learners' texts online. Similarly, Wolsey (2008) supports instructors' indirect feedback in fostering learners' self-corrections, reflections, and online learning.

Other researchers (e.g., Srichanyachon, 2012) have argued that teacher feedback should address learners' needs in writing and enable them to progress to writing beyond the current stage, regardless of whether such feedback is direct or indirect. However, others have argued that indirect feedback is more effective for learners in self-problem-solving (Lalande, 1982) or self-error correction (Ferris \& Roberts, 2001; Hyland, 2003), seeking clarification and reflecting on their learning tasks (Miceli, 2006).

In contrast, some researchers have argued in favor of direct feedback. For instance, Conrad and Goldstein (1999) reported that directives resulted in the most text revisions by students. Similarly, Williams (2004) found that explicit and direct teacher feedback generated more revisions from students than implicit and indirect feedback because such feedback provided explicit explanations of issues, which were more likely to be revised.

So far the above review has focused on research on the patterns of teacher feedback, specifically the functions of teacher feedback and direct versus indirect feedback. The foci of teacher feedback are very pertinent to this study. They refer to areas of focus targeted by teachers through written feedback on students' writing. In that respect, previous research has questioned what areas of writing teachers should target through feedback. Researchers have come up with different findings and different arguments. First, teacher feedback focuses on local issues in writing (e.g., grammar, vocabulary, and punctuation) more than global issues (e.g., content and organization; Zamel, 1985). Second, Sheppard (1992) and Truscott (1996) argued that teacher feedback should not focus on local issues because students are likely to misinterpret such feedback and turn their attention away from other deeper or global issues in their writing. On the other hand, Chandler (2000) found that feedback on local issues resulted in substantial revisions of texts and better organization of ideas. Ferris (1997) argued that teacher feedback should focus on both local and global issues because both areas are important to enhance learners' writing. Most of the research discussed here has been grounded in the cognitive perspective and sociocultural theories by looking at feedback as a way to mediate learners' cognitive processes, such as comprehension of the flaws and issues in their writing, and also as a means to assist them in fixing such issues to improve their writing. Although considerable research exists on teacher feedback, the role of feedback in eliciting learners' text revisions and interactions about writing remains fairly unexplored-despite being a topic of significant importance.

\subsection{Teacher Feedback and Students' Interactions}

Some studies have also looked at the role of teacher feedback in engaging ESL/EFL learners in revising their writing. For instance, Hyland (1998) found that a teacher's feedback could help students engage in text revisions in two different ways. First, most of the students' revisions indicate they followed the suggestions provided by the teacher. In this regard, the revisions resulting from teacher feedback focused on two areas: academic issues, such as referencing and level of formality, and language, such as meaning and form. Second, the feedback additionally stimulated the students to revise their texts beyond the issues identified by the teacher. Although some revisions were found not to have resulted from the teacher's feedback, such feedback nonetheless played an influential role in improving the learners' written texts. According to Williams (2004), teacher feedback led to more surface-level revisions, such as grammar and vocabulary, as most of these revisions were traced to the teacher's feedback. Williams also argued that modeling feedback is important since it is one way in which teachers scaffold learners on difficult tasks. Hence, the author emphasizes modeled feedback from the sociocultural perspective. Similarly, Kazemi et al. (2018) reported that, as a result of teacher feedback, students showed a high level of engagement in their writing, as indicated by their text revisions with respect to surface level-errors. 
In Williams' (2004) study, an interesting finding indicates that as student writers had to respond to the tutor's feedback in conferencing sessions, they also engaged in interactions. Some clear features of such interactions were identified as key factors in facilitating students' text-based revisions, negotiations, clarification by teacher, active participation of the students, task-organization by teachers, emphasis on the goals of revisions, and modeling or instructing. Williams concluded by pointing out the importance of learners' responses to instructor feedback in establishing teacher-learner interactions. Alvarez et al. (2012) also analyzed learners' responses to teacher feedback and found that the learners engaged in clarifications, justifications, disagreements, and elaboration of their arguments. Moreover, Alvarez et al. claimed that teacher feedback supports students' cognitive processes, including critical thinking. Such findings support the view that teacher feedback is a two-way interaction with students in online collaborative writing (Carless, Salter, Yang, \& Lam, 2011; Guasch, Espasa, Alvarez, \& Kirschner, 2013; Nicol \& Macfarlane-Dick, 2006).

Few studies have also focused on the role of asynchronous technologies in facilitating teacher feedback on ESL/EFL learners' writing. For instance, Shintani (2016) and Shintani and Aubrey (2016) showed that asynchronous technological tools facilitated teachers' feedback. Moreover, in Shintani's (2016) study where the researcher investigated the effect of synchronous and asynchronous corrective feedback through Google Docs concluded that computer-mediated synchronous feedback could create an interactive writing process among students as well as promote self-correction and noticing the gap. Other studies (Arslan \& Şahin-Kızıl, 2010; Ducate \& Lomicka, 2008; Lee, 2009) suggest that blogs play an important role in facilitating instruction in writing, including teacher feedback on students' writing. However, the present study used blogging as a platform to investigate teacher asynchronous direct and indirect feedback and how it promotes students' interaction on EFL learners' writing.

\section{Method}

\subsection{Research Design}

Based on the issues and gaps identified in previous research, the present paper presents a qualitative case study that focused on one EFL writing class at one of the largest universities in Saudi Arabia. The use of a case study suits the investigation of a single (or case) unit, which here is one undergraduate class at one public Saudi Arabian university. Initially, I analyzed the data using a qualitative analysis. I then quantified the patterns and categories to better understand their frequency distributions.

\subsection{Study Setting}

I conducted the study in the Department of English at a university located in a socioeconomically middle-class area in central Saudi Arabia. This university has approximately 20,000 students in diverse graduate and undergraduate majors, including English, Education, and Applied Science. In this study, one writing class comprised 15 EFL students (10 females and 5 males; see Table 1). The English program takes 4 academic years and consists of 8 levels. Each level is one semester long (spring or fall) and lasts 3 months. At the time of the study, the participants' ages ranged from 20 to 22 years old. According to the department entrance exam, by the third-year level, students demonstrate an intermediate level of English proficiency. They are of different nationalities but share the same native language (Arabic), and English is their second language. All of the students in the study majored in English. Prior to their participation, I gave the students consent forms and informed them of the purpose of the study.

To protect the students' and instructor's anonymity, I created pseudonyms comprising the initials of each student's first and last names (e.g., TI) and the letter T to denote the writing teacher; I used these notations in all sample feedback, responses, and text revisions presented in the findings of the paper. 
Table 1. Profile of the samples in the current study

\begin{tabular}{lll}
\hline Pseudonym & Nationality & Gender \\
\hline NS & Sudan & F \\
AK & Syria & M \\
TI & Kuwait & F \\
RE & Saudi Arabia & F \\
ZN & Yemen & F \\
AM & Oman & M \\
TS & Egypt & F \\
LR & Yemen & M \\
FA & Yemen & F \\
SM & Saudi Arabia & F \\
PR & Kuwait & M \\
YR & Saudi Arabia & F \\
MD & Sudan & F \\
NA & Yemen & M \\
SA & Saudi Arabia & F \\
\hline
\end{tabular}

\subsection{Teacher Asynchronous Feedback Sessions}

This study focused on a writing course over Semester 1 of the academic year 2016-2017. At the end of the course, the students had to be able to write effective paragraphs in English. The focus of this study is on free paragraph writing.

Due to the time restrictions and the traditional feedback practices on printed papers, I implemented asynchronous tools for the teacher to provide feedback. As a result, the teacher created a blog as a platform for teacher asynchronous feedback sessions.

The instructor assigned students to engage in free paragraph writing (see Table 2). In this stage they had to select topics according to their own interests, write their paragraphs using Microsoft Word documents, and email the documents to the instructor. In the next stage, the instructor created the blog as a platform for online feedback and for the scheduling of the online sessions.

Table 2. Description of the activities

\begin{tabular}{ll}
\hline Activity & Description \\
\hline Writing & $\begin{array}{l}\text { The students were assigned free paragraph writing and emailed the paragraph to the instructor (first draft). } \\
\text { Preparation }\end{array}$ \\
$\begin{array}{l}\text { The students learned about the teacher feedback activities and gave their consent. } \\
\text { Feedback session 1 }\end{array}$ & $\begin{array}{l}\text { The teacher created the blog, inviting students to create their accounts } \\
\text { The teacher provided feedback on the first drafts, and students discussed, revised, and emailed their second } \\
\text { drafts to the instructor. }\end{array}$ \\
Feedback session 2 & $\begin{array}{l}\text { The teacher provided feedback on the second drafts; students responded, revised the drafts in the blog, and } \\
\text { emailed these third drafts to the instructor as the final submission for evaluation. }\end{array}$ \\
\hline
\end{tabular}

The first session of teacher feedback covered five weekly 3-hour discussions in the blogs. During the first session, the students received asynchronous teacher feedback on their first drafts and had to revise them and email them to the instructor as second drafts. They repeated the same cycle with the second drafts, which students had to revise accordingly. This session ended with the revised versions, which were labeled as third or final drafts.

In each weekly feedback discussion, the teacher and the students had to be present online. The teacher posted the paragraph of a given student together with feedback provided through asynchronous comments. The instructor encouraged the student to respond, take notes, and revise the text during or just after the discussion to keep the discussion active. Moreover, the instructor asked the student's peers to read and follow the teacher's feedback, and then respond should the student fail to identify the issues and carry out appropriate revisions. In each session, the instructor and peer students gave feedback on three to four paragraphs, and the authors and their peers then revised the paragraphs.

\subsection{Data Collection and Analysis}

In this study, I collected the following three types of data: (1) teacher feedback, (2) students' subsequent text 
revisions, and (3) students' responses to teacher feedback. I collected teacher feedback and students' responses as asynchronous threads of discussions at the end of each session; I then saved and organized these discussion threads in MS Word files. The third type of data consists of the students' first drafts, second drafts, and third drafts, which I saved and organized in separate files for each individual learner.

For the present study I performed a content analysis of the three types of data to be carried out in several steps (see Table 3). The first step consisted of analyzing the teacher feedback in the following three phases: language functions, directness versus indirectness, and foci of feedback. I analyzed a total of 832 teacher feedback comments provided on all students' written drafts. First, I coded each instance of feedback posted by the teacher through asynchronous comments in relation to its function, based on several patterns found in the literature (see Appendix A1). The second phase of the first step involved another round of analysis of teacher feedback in terms of its directness versus indirectness (see Appendix A2). Whereas direct feedback tends to provide learners with direct correction of a particular error in writing and/or a detailed, explicit explanation of such an error, indirect feedback points to the error indirectly by highlighting it, asking a question about it, and indirectly directing students to revise that part of their text. The third phase of this step focused on coding each item of teacher feedback in terms of focus area, based on the course's criteria with respect to writing: content and ideas, organization, vocabulary, grammar, and mechanics of texts (adopted from Montgomery \& Baker, 2007; see Appendix A3).

Table 3. Summary of the data analysis

\begin{tabular}{ll}
\hline Step & Description \\
\hline Step 1 & Analysis of teacher feedback \\
Step 2 & Analysis of the students' subsequent text revisions \\
Step 3 & Analysis of the students' responses to teacher feedback \\
Step 4 & Analysis of the link between teacher feedback and text revisions \\
Step 5 & Analysis of the interactivity of teacher feedback and students' responses \\
\hline
\end{tabular}

In the second step 1 compared the students' first, second, and third (final) drafts. I highlighted the changes as text revisions and coded them by their focus area: ideas and content (e.g., addition of new ideas), organization, vocabulary, grammar, and mechanics (see Appendix B). The coding schemes of these areas of text revisions were consistent with the prior coding scheme in Step 1 and the writing instruction in the course.

The third step focused on analyzing the students' responses to teacher feedback (1032 responses over the study period), each of which was analyzed based on the literature review (e.g., Alvarez et al., 2012). However, the analysis allowed for new categories to emerge from the data. Hence, I clustered the students' responses into 10 final categories (see Appendix C1). Moreover, I analyzed the foci of the responses based on the five above-mentioned focus areas of teacher feedback, and I categorized other responses as procedural and social talks. Appendix C2 presents examples of students' responses.

The fourth step involved a textual analysis of the students' text revisions in relation to teacher feedback and students' responses. This was intended to find any evidence of the link between students' text revisions and teacher feedback, specifically direct and indirect feedback. Thus, any text revision was linked to the asynchronous feedback and responses. The text revisions which were not triggered by teacher feedback were labeled as self-made or initiated revisions. From this analysis, most of the learners' text revisions were linked to two sources: (1) teacher direct and indirect feedback and (2) peer fragment corrections. The remaining text revisions were coded as self-corrections.

The final step aimed to identify instances of interactivity between teacher feedback and students' responses in the asynchronous discussions. The focus was on whether teacher feedback, particularly the questions addressed to all learners, initiated and extended interactions. This step ended by selecting one thread of interactions to particularly exemplify such interactivity. The examples show how teacher feedback created a space for interaction by prompting learners' written responses to the instructor's questions.

Two independent coders performed the analysis of all the above data, based on their discussions of the codes prior to the analysis. At the end of the analysis phase, the coders shared the coded data via Google Docs to negotiate their agreements/disagreements about the patterns and categories. This laborious coding and recoding continued until they reached overall agreement. Finally, the coders quantified the patterns of teacher feedback, students' text revisions, and responses across the two sessions of teacher asynchronous feedback. 


\section{Results}

\subsection{Types of Teacher Feedback}

\subsubsection{Functions of Teacher Feedback}

The five patterns of teacher asynchronous feedback in terms of function are as follows: question, statement, suggestion, directive, and correction. Table 4 shows that the teacher provided a total of 832 instances of feedback, of which 421 were in the first session (on the first drafts) and 411 were in the second session (on the second drafts). Regarding the patterns, correction formed the most important category, followed by directive feedback, statement, suggestion, and question.

Table 4. Frequency (number and percentage) of asynchronous teacher feedback

\begin{tabular}{llll}
\hline Categories & Session 1 & Session 2 & Total \\
\hline Question & $45(6 \%)$ & $87(10 \%)$ & $132(16 \%)$ \\
Statement & $91(11 \%)$ & $62(8 \%)$ & $153(19 \%)$ \\
Suggestion & $41(5 \%)$ & $103(12 \%)$ & $144(17 \%)$ \\
Directive & $102(12 \%)$ & $83(10 \%)$ & $185(22 \%)$ \\
Correction & $142(17 \%)$ & $76(9 \%)$ & $218(26 \%)$ \\
Overall & $421(51 \%)$ & $411(49 \%)$ & $832(100 \%)$ \\
\hline
\end{tabular}

The total instances of corrective feedback are almost similar in both sessions, but the other types of feedback vary by session. For instance, while correction was the most frequent type of teacher feedback in the first session, followed by directive, in the second session, suggestion was most frequent, followed by question. However, the number of statements decreased between the first session and the second session. While the number of items in the suggestion and question categories increased, the number of corrections, directives, and statements declined. This suggests the teacher increased the use of indirect/implicit feedback in the form of questions and suggestions.

\subsubsection{Directness Versus Indirectness of Teacher Feedback}

The teacher posted $452(54 \%)$ instances of indirect feedback and $380(46 \%)$ instances of direct feedback (see Table 5). The use of direct feedback declined over the two sessions. On the other hand, instances of indirect teacher feedback increased from the first session to the second. This supports the above result on the increasing number of suggestions and questions, which tended to be indirect rather than direct feedback.

Table 5. Frequency (number and percentage) of direct versus indirect teacher feedback

\begin{tabular}{llll}
\hline Categories & Session 1 & Session 2 & Total \\
\hline Direct feedback & $265(32 \%)$ & $115(14 \%)$ & $380(46 \%)$ \\
Indirect feedback & $156(19 \%)$ & $296(35 \%)$ & $452(54 \%)$ \\
Overall & $421(51 \%)$ & $411(49 \%)$ & $832(100 \%)$ \\
\hline
\end{tabular}

\subsubsection{Foci of Teacher Feedback}

In this study, teacher feedback focused on the following five areas of writing: content and ideas, organization or flow of ideas, vocabulary, grammar, and mechanics; a sixth category of feedback was general/not specific (see Table 6). Overall, grammar was the most important area of focus for teacher feedback, followed by vocabulary, mechanics, organization, content, and general. This suggests the focus of feedback on local issues (grammar, vocabulary, and mechanics) exceeded the focus on global issues (content/ideas and organization).

Table 6. Frequency (number and percentage) of the focus of teacher feedback

\begin{tabular}{llll}
\hline Categories & Session 1 & Session 2 & Total \\
\hline Content & $43(5 \%)$ & $38(5 \%)$ & $81(10 \%)$ \\
Organization & $39(5 \%)$ & $48(6 \%)$ & $87(11 \%)$ \\
Vocabulary & $112(13 \%)$ & $125(15 \%)$ & $237(28 \%)$ \\
Grammar & $135(16 \%)$ & $121(14 \%)$ & $256(30 \%)$ \\
Mechanics & $68(8 \%)$ & $49(6 \%)$ & $117(14 \%)$ \\
General/not specific & $24(3 \%)$ & $30(4 \%)$ & $54(7 \%)$ \\
Overall & 421 & 411 & $832(100 \%)$ \\
\hline
\end{tabular}


Most teacher feedback in the first session focused on grammar, followed by vocabulary, mechanics, and content, while organization and general scored the lowest frequency and percentages. However, in the second session, feedback focused mostly on vocabulary, followed by grammar, mechanics, and organization, while the lowest percentages corresponded to content and general feedback. Thus, while vocabulary, organization, and general feedback increased between the first and second sessions, the feedback on grammar, mechanics, and content declined. The increase can be due to the following: (1) some students failed to successfully revise their first drafts in terms of vocabulary and organization, based on teacher feedback in the first session; or (2) students made more mistakes in vocabulary and organization. However, the decreasing amount of teacher feedback on grammar, mechanics, and content suggests the students successfully corrected their mistakes based on teacher feedback in the first session.

\subsection{The Role of Teacher Feedback in Engaging Students in Writing}

\subsubsection{Engaging Learners in Text Revisions}

In this study, the EFL learners' subsequent text revisions were tracked and analyzed in terms of the five focus areas: content and ideas of writing, organization or flow of ideas, vocabulary, grammar, and mechanics (see Table 7). Out of the 1102 total text revisions, the majority were vocabulary-related text revisions, followed by revisions that focused on grammar, mechanics, content and ideas, and the organization of ideas. This is consistent with teacher feedback focusing mostly on local issues in writing.

Table 7. Frequency (number and percentage) of learners' text revisions

\begin{tabular}{llll}
\hline Categories & Session 1 & Session 2 & Total \\
\hline Content and ideas & $62(6 \%)$ & $51(4 \%)$ & $113(10 \%)$ \\
Organization & $44(4 \%)$ & $52(5 \%)$ & $96(9 \%)$ \\
Vocabulary & $169(15 \%)$ & $205(19 \%)$ & $374(34 \%)$ \\
Grammar & $192(17 \%)$ & $161(15 \%)$ & $353(32 \%)$ \\
Mechanics & $97(9 \%)$ & $69(6 \%)$ & $166(15 \%)$ \\
Overall & $564(51 \%)$ & $538(49 \%)$ & $1102(100 \%)$ \\
\hline
\end{tabular}

Comparison of the two sessions shows variation in the number and percentage of each category of text revisions. The number of learners' text revisions focusing on vocabulary and organization of ideas increased from 169 $(15 \%)$ and $44(4 \%)$, respectively, in the first session to $205(19 \%)$ and $52(5 \%)$ in the second session. In contrast, revisions focusing on grammar, mechanics, and content and ideas all decreased between the first and second sessions (see Table 7). This echoes the increasing focus of teacher feedback on vocabulary and organization and decreasing focus on grammar, mechanics, and content.

Analysis of the link between teacher feedback and the learners' subsequent revisions shows that the latter are linked to three sources: (1) direct teacher feedback, (2) indirect teacher feedback, and (3) peer- and self-corrections (see Table 8). Indirect teacher feedback triggered the largest proportion of text revisions, both in the first and second sessions. Direct feedback was responsible for the second largest proportion of revisions, both overall and per session. Finally, peer- and self-corrections prompted the fewest text revisions. Such results indicate the following: (1) teacher feedback was the greatest overall influence on learners' subsequent text revisions, and (2) teacher feedback also triggered peer- and self-corrections. Moreover, the quality of the text revisions made by the students was satisfactory since they addressed the various issues detected in their second drafts. This led to improvement of their writing as shown in their final drafts.

Table 8. Subsequent revisions based on direct versus indirect teacher feedback

\begin{tabular}{llll}
\hline Categories & Session 1 & Session 2 & Total \\
\hline Based on direct feedback & $256(23 \%)$ & $106(10 \%)$ & $362(33 \%)$ \\
Based on indirect feedback & $148(13 \%)$ & $279(25 \%)$ & $427(38 \%)$ \\
Based on peer- and self-corrections & $160(15 \%)$ & $153(14 \%)$ & $313(29 \%)$ \\
Overall & $564(51 \%)$ & $538(49 \%)$ & $1102(100 \%)$ \\
\hline
\end{tabular}

\subsubsection{Engaging Learners in Various Responses}

Learners posted a total of 1032 comments in response to teacher feedback over the study period (see Table 9 and Appendix C1). Students' responses that functioned as issue identification and evaluation were the most 
frequently used. The frequency of these response patterns also varied between sessions, with issue identification and evaluation being the most frequent focus of learners' responses in the first session, and evaluation and issue identification most frequent in the second session. Moreover, while suggestion was the least frequent function in the first session, explanation was least frequent in the second session. In addition, all patterns of the EFL learners' responses to teacher feedback increased in the second session except explanation, agreement versus disagreement, and confirming understanding. Examples of learners' responses to teacher feedback are provided in Appendix C2.

Table 9. Frequency (number and percentage) of the functions of learners' responses

\begin{tabular}{llll}
\hline Categories & Session 1 & Session 2 & Total \\
\hline Question & $32(3 \%)$ & $45(4 \%)$ & $77(7 \%)$ \\
Suggestion & $29(3 \%)$ & $49(5 \%)$ & $78(8 \%)$ \\
Evaluation & $61(6 \%)$ & $98(9 \%)$ & $159(15 \%)$ \\
Clarification & $56(5 \%)$ & $62(6 \%)$ & $118(11 \%)$ \\
Explanation & $38(4 \%)$ & $22(2 \%)$ & $60(6 \%)$ \\
Justification & $42(4 \%)$ & $47(5 \%)$ & $89(9 \%)$ \\
Agreeing/disagreeing & $59(6 \%)$ & $51(5 \%)$ & $110(11 \%)$ \\
Confirming understanding & $48(5 \%)$ & $34(3 \%)$ & $82(8 \%)$ \\
Issue identification & $71(7 \%)$ & $92(9 \%)$ & $163(16 \%)$ \\
Others & $41(4 \%)$ & $55(5 \%)$ & $96(9 \%)$ \\
Overall & $477(47 \%)$ & $555(53 \%)$ & $1032(100 \%)$ \\
\hline
\end{tabular}

Learners' responses follow the same pattern as that of teacher feedback in terms of foci except for the last category, labeled procedure and social talk, which focused on matters irrelevant to the revisions. From the students' total responses across both sessions, the highest focus areas were grammar and vocabulary, followed by mechanics, organization, content and ideas, and finally, procedure and social talk (see Table 10). While grammar and vocabulary were the focus of the highest number of responses in the first session, in the second session these were reversed. In both sessions, however, procedure and social talks received the least attention from the students. Finally, all focus areas of the students' responses increased in the second session except for grammar and mechanics, which decreased.

Table 10. Frequency (number and percentage) of the foci of learners' responses to teacher feedback

\begin{tabular}{llll}
\hline Categories & Session 1 & Session 2 & Total \\
\hline Content & $45(4 \%)$ & $61(6 \%)$ & $106(10 \%)$ \\
Organization & $42(4 \%)$ & $65(6 \%)$ & $107(11 \%)$ \\
Vocabulary & $109(11 \%)$ & $152(14 \%)$ & $261(25 \%)$ \\
Grammar & $141(14 \%)$ & $139(13 \%)$ & $280(27 \%)$ \\
Mechanics & $99(10 \%)$ & $83(8 \%)$ & $182(18 \%)$ \\
Procedure and social talk & $41(4 \%)$ & $55(5 \%)$ & $96(9 \%)$ \\
Overall & $477(47 \%)$ & $555(53 \%)$ & $1032(100 \%)$ \\
\hline
\end{tabular}

\subsubsection{Engaging Learners in Extended Interactions}

The qualitative analysis of the learners' responses to teacher feedback in the online asynchronous feedback sessions identified teacher-learner and learner-learner interactions that were extended by the teacher's indirect/implicit feedback, especially the use of questions. Excerpt 1 shows how the teacher's first question, which sought clarification, initiated learners' interactions, and how the two subsequent questions, which functioned as a suggestion and a request, extended learners' interactions. As a result, learners responded to the teacher and attempted to provide good alternatives (e.g., verbs, phrases) to enhance the meaning of the sentence in one draft. Eventually, RE provided the best alternative that expressed the accurate intended meaning, and ZN used it in the sentence of the revised paragraph. Moreover, the comments illustrate how the students tried to interpret the meaning of the linguistic alternatives based on various sources, such as previous knowledge (TI and $\mathrm{RE}$ ), guessing (MD), and translating it into their mother tongue (Arabic; PR) in order to select the best revision for the draft. 
Excerpt 1. An example showing learners' extended interactions

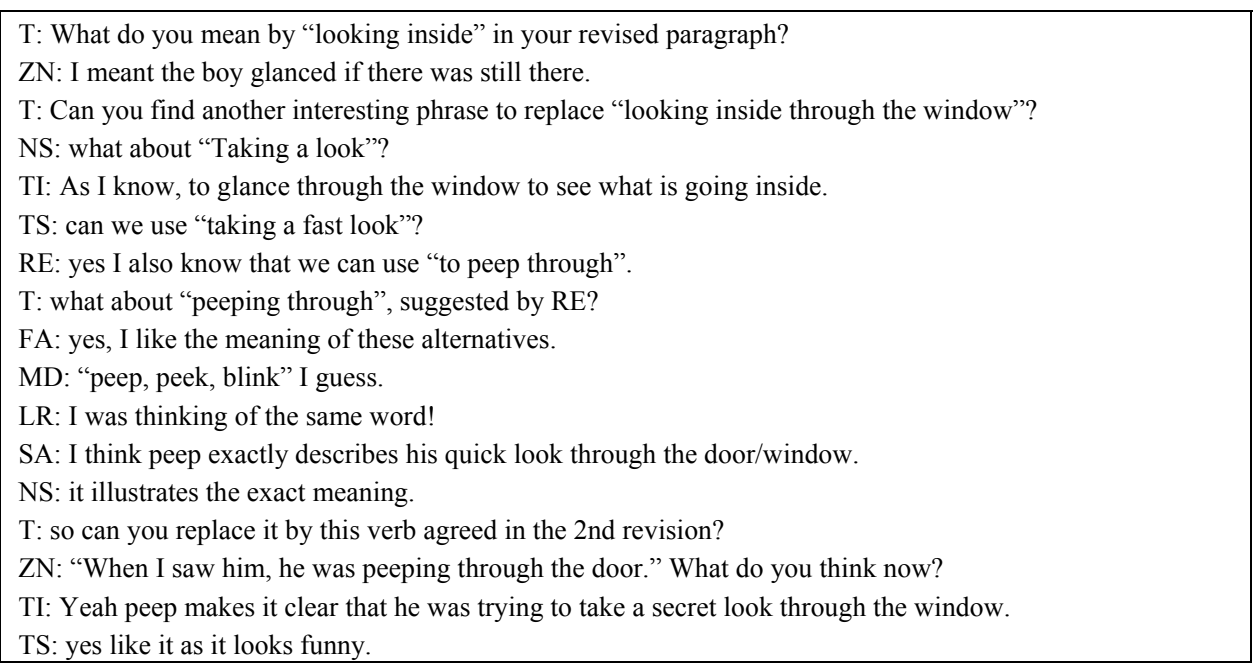

\section{Discussion and Implications}

This study explored the patterns of asynchronous teacher feedback on EFL learners' writing in two sessions over one semester of the academic year 2016-2017. Teacher feedback falls into the following five categories: corrections, directives, statements, suggestions, and questions. This study's findings corroborate the findings of several previous studies on the language functions of teacher feedback (Conrad \& Goldstein, 1999; Ferris, 1997). However, whereas in Treglia's (2009) study, the majority of teacher feedback functioned as requests, with clarifications and suggestions accounting for the least frequently used types of feedback, in the present study, most teacher feedback came in the form of corrections of students' issues in writing, and questions were the least frequently used type of feedback. The present results also contradict those reported by Kazemi et al. (2018), which state that directive is the most frequently used type of teacher feedback. The reason behind these different results could be due to the preference of the teacher. That is, the teacher in the current study preferred to use questions as the most frequent form of feedback to stimulate learners' responses and text revisions. Another reason could be the difference in the issues in the writing detected by the teacher. This suggests that when questioned by the teacher, learners are expected to understand and detect issues - such as local issues - in their writing.

The findings of this study resemble the results reported by Alvarez et al. (2012) where the most frequent teacher feedback was directive, whereas the least frequently used feedback was through giving a summary. This could be due to the EFL learners' failure to accurately revise their writing based on teacher feedback, especially in the case of indirect or implicit feedback. As a result, the teacher in this study had to use feedback mostly in the form of corrections of issues/errors in writing. Moreover, questions compose the least frequently used category, which supports what was reported by Alvarez et al. Yet, in the present study, teacher corrections, along with directives and statements, decreased in frequency of use in the second session, while other patterns of feedback, including questions and suggestions, increased. This suggests the students were more responsive to these two kinds of teacher feedback and revised their texts accordingly. Another possible interpretation of such findings is that the teacher increased the use of these two types of feedback because the third drafts might not have contained as many issues as the second drafts.

In this study, I also analyzed teacher feedback in relation to directness versus indirectness and this led to interesting results. Like several previous studies (Alvarez et al., 2012; Chandler, 2000; Ferris, 1997; Williams, 2004; Wolsey, 2008), this study indicates that the teacher used both direct and indirect feedback to address EFL learners' writing. Moreover, the teacher used more indirect feedback than direct feedback. Yet, the amount of both types of feedback varied. Indeed, the direct teacher feedback exceeded the indirect feedback in the first session, but the opposite occurred in the second session. The increase in the teacher's use of indirect feedback in the second session suggests that, over time, the students appeared to understand indirect feedback and revised their writing accordingly.

As an interesting aspect of teacher feedback, several studies have investigated their foci (Sheppard, 1992; Truscott, 1996; Zamel, 1985). Here the analyses revealed that most students appear to struggle with accurate use of language in writing their drafts, particularly with vocabulary and grammar. 
The above findings do not suggest that the EFL learners did not struggle with content and idea development, organization of ideas, and use of mechanics in their writing. Issues in these global areas of writing also received considerable teacher feedback. However, the findings indicate that the most attention was paid to grammar and vocabulary and, therefore, support the argument that teacher feedback should focus on both local and global issues (Ferris, 2003).

Regarding the second research question as to the role of teacher feedback in engaging EFL learners, the findings illustrated how asynchronous teacher feedback affected students' revisions in terms of content and ideas, organization, grammar, vocabulary, and mechanics. However, teacher feedback engaged learners more in revising vocabulary, grammar, and mechanics than in revising content, ideas, and organization. This is in agreement with several studies on teacher feedback and students' engagement in text revisions (Kazemi et al., 2018; Williams, 2004). Moreover, from the process approach to writing, teacher feedback enables learners to refine their texts, especially in the revision stage (Ferris, 1997; Harran, 2011; Zamel, 1985).

Furthermore, EFL learners made the majority of text revisions based on indirect teacher feedback. This particular finding supports the body of research arguing in favor of indirect teacher feedback on the basis that it engages learners in more substantial text revisions (Alvarez et al., 2012; Ferris \& Roberts, 2001; Hyland, 2003; Lalande, 1982; Wolsey, 2008).

Yet, this finding should not imply that direct feedback is ineffective for EFL students. Indeed, direct teacher feedback generated the second largest proportions of text revisions, which is in line with other studies (Conrad \& Goldstein, 1999; Williams, 2004). Moreover, our study suggests that teacher feedback plays a crucial role in triggering peer- and self-corrections of writing among learners (Ferris \& Roberts, 2001; Hyland, 1998, 2003).

As shown in this study, teacher feedback triggers student responses. Some researchers (Lalande, 1982; Miceli, 2006; Williams, 2004; Wolsey, 2008) argued that teacher feedback should encourage and engage students to respond since they must then negotiate and clarify meaning, problem-solve, and reflect on their learning. This study also identified various patterns of responses, such as clarification, evaluation, and questions. Moreover, the foci of the EFL learners' responses illustrate how the learners reflected on issues in their writing in the five categories defined above.

Another interesting finding of this study is that asynchronous teacher feedback engages learners in extended online interactions. This contributes to our understanding of teacher feedback from the sociocultural perspective (Vygotsky \& Cole, 1978). Teacher feedback can be interactive when formulated through questions or other implicit forms that seek clarifications of feedback, clarify misunderstandings, and negotiate intended meaning and ideas in writing (Carless et al., 2011; Guasch et al., 2013; Lee, 2014; Nicol \& Macfarlane-Dick, 2006). This study also supports the argument that implicit teacher feedback in the form of questions can serve as scaffolds to learners in their cognitive development (Aljaafreh \& Lantolf, 1994; Lantolf, 2000) and writing (Bitchener \& Ferris, 2012; Lee, 2014).

The teacher's online presence during feedback sessions enabled him to continue posting questions addressed not only to a particular individual author but also to other peers, in case the author failed to identify and solve issues in his or her writing. This subsequently created peer or learner-learner interactions, which were reported in other sociocultural studies (Saeed \& Ghazali, 2017). Hence, this study supports the argument that asynchronous tools facilitate learners' interactions in online discussions on writing.

The findings of the present study have underlying implications for ESL/EFL writing instruction. First, ESL/EFL learners need assistance in their writing from capable individuals who are usually their instructors. This assistance, as evidenced in this study, takes the form of written English feedback from teachers. This suggests that feedback plays a dual role in writing: (1) assisting learners to detect and correct issues in their writing, and (2) using English as a means of communication and interaction with the instructor. What makes written English an important mode of feedback is the use of asynchronous technologies, including blogs. Blogs provide learners with sufficient opportunities to read and reflect on their teacher's feedback, to better understand such feedback, and, consequently, to apply it to their writing through text revisions. Moreover, constructive teacher feedback should not only allow learners to revise the issues articulated by the instructor through written comments, but also trigger self-initiated text revisions.

The way in which learners respond to teacher feedback suggests that the value of such feedback is maximized by opportunities provided to learners to negotiate their issues and interact with the instructor. This particular finding can be considered the main contribution of this study to knowledge about teacher feedback that was advocated by several studies. It also indicates that learners are no longer passive learners who act as mere receivers of feedback, but that they are active in constructing knowledge. While previous studies have documented teacher 
feedback as one way of providing comments on students' writing, this study adds that feedback is a dual interactive process in which the teacher acts as the provider and the learners as active receivers, respondents, and sometimes peer reviewers. Interaction is an important component of constructive learning, as learners assume active roles. This is why there is an urgent need for change in the traditional classroom scenario, especially in the context of EFL teaching. Another implication of this particular finding is that feedback, when effectively constructed by teachers, engages learners in using English even more, an opportunity that might not be available outside the classroom in the context of EFL.

\section{Conclusion}

This study was conducted to identify the patterns of teacher feedback on free paragraph writing of EFL learners over two sessions. It also aimed to investigate how teacher feedback engaged learners in writing, particularly in the revision stage. Although this study provides encouragement for ESL/EFL instructors to assist their students in refining their writing and for researchers in studying interactive teacher feedback practices, it also presents some limitations. First, the study was conducted on a single EFL writing class. The relatively small number of learners in the study might have affected the results, which should therefore be interpreted with great caution. Another limitation is that, although the findings provided evidence of students' improvement in writing after receiving feedback, as implied through revisions to their drafts, such improvement in writing was not assessed through grades. Therefore, future research aiming to determine the extent to which teacher feedback was efficient in improving learners' writing needs to take into account the assessment/evaluation of their first drafts compared to second and final drafts. A final limitation of this study is that this study did not take into consideration students' grades/marks of their final drafts of paragraphs. This is because the study was not intended to evaluate students' performance in writing. However, our focus was exclusive to the process of students' learning in writing promoted through instructor's asynchronous feedback. Therefore, future research can use an experimental study in which students' first drafts (pre-experimental tasks) and final drafts (post-experimental tasks) are marked and their performance in writing is evaluated accurately. Moreover, in this study, quantification of teacher feedback and students' responses and text revisions did not involve investigation at an individual learner level (e.g., how much feedback did each learner receive; how many responses were posted by each individual; how many revisions were made by each learner) due to the large amount of data to be collected. Hence, future research could focus on the individual level to investigate individual variations in response to feedback. Future studies could also examine EFL learners' reflections on teacher feedback to provide a more comprehensive picture of their preferences in terms of patterns of feedback. A final interesting possibility for future investigation is the comparison of various modes of teacher feedback, such as oral versus online feedback, to determine the effect these modes have on students' responses and text revisions.

\section{References}

Aljaafreh, A. L., \& Lantolf, J. P. (1994). Negative feedback as regulation and second language learning in the zone of proximal development. The Modern Language Journal, 78(4), 465-483. https://doi.org/10.1111/j.1540-4781.1994.tb02064.x

Alvarez, I., Espasa, A., \& Guasch, T. (2012). The value of feedback in improving collaborative writing assignments in an online learning environment. Studies in Higher Education, 37(4), 387-400. https://doi.org/10.1080/03075079.2010.510182

Arslan, R. Ş., \& Şahin-Kızıl, A. (2010). How can the use of blog software facilitate the writing process of English language learners? Computer Assisted Language Learning, 23(3), 183-197. https://doi.org/10.1080/09588221.2010.486575

Bitchener, J., \& Ferris, D. R. (2012). Written corrective feedback in second language acquisition and writing. New York, NY: Routledge. https://doi.org/10.4324/9780203832400

Bitchener, J., \& Knoch, U. (2008). The value of written corrective feedback for migrant and international students. Language Teaching Research, 12(3), 409-431. https://doi.org/10.1177/1362168808089924

Carless, D., Salter, D., Yang, M., \& Lam, J. (2011). Developing sustainable feedback practices. Studies in Higher Education, 36(4), 395-407. https://doi.org/10.1080/03075071003642449

Chandler, J. (2000). The efficacy of error correction for improvement in the accuracy of L2 student writing. Paper presented at the AAAL Conference, Vancouver, Canada.

Conrad, S. M., \& Goldstein, L. M. (1999). ESL student revision after teacher-written comments: Text, contexts, and individuals. Journal of Second Language Writing, 8(2), 147-179. https://doi.org/10.1016/S1060-3743(99)80126-X 
Ducate, L. C., \& Lomicka, L. L. (2008). Adventures in the blogosphere: From blog readers to blog writers. Computer Assisted Language Learning, 21(1), 9-28. https://doi.org/10.1080/09588220701865474

Ferris, D. R. (1997). The influence of teacher commentary on student revision. TESOL Quarterly, 31(2), 315339. https://doi.org/10.2307/3588049

Ferris, D. R. (2003). Response to student writing: Implications for second language students. New York, NY: Routledge.

Ferris, D., \& Roberts, B. (2001). Error feedback in L2 writing classes: How explicit does it need to be? Journal of Second Language Writing, 10(3), 161-184. https://doi.org/10.1016/S1060-3743(01)00039-X

Flower, L., \& Hayes, J. R. (1981). A cognitive process theory of writing. College Composition and Communication, 32(4), 365-387. https://doi.org/10.2307/356600

Guasch, T., Espasa, A., Alvarez, I. M., \& Kirschner, P. A. (2013). Effects of feedback on collaborative writing in an online learning environment. Distance Education, 34(3), 324-338. https://doi.org/10.1080/01587919.2013.835772

Harran, M. (2011). What higher education students do with teacher feedback: Feedback-practice implications. Southern African Linguistics and Applied Language Studies, 29(4), 419-434. https://doi.org/10.2989/16073614.2011.651941

Hyland, F. (1998). The impact of teacher written feedback on individual writers. Journal of Second Language Writing, 7(3), 255-286. https://doi.org/10.1016/S1060-3743(98)90017-0

Hyland, F. (2003). Focusing on form: Student engagement with teacher feedback. System, 31(2), 217-230. https://doi.org/10.1016/S0346-251X(03)00021-6

Kazemi, M., Abadikhah, S., \& Dehqan, M. (2018). A comparison of teacher feedback versus students' joint feedback on EFL students' composition. The IUP Journal of English Studies, 13(1), 90-102.

Keh, C. L. (1990). Feedback in the writing process: A model and methods for implementation. ELT Journal, 44(4), 294-304. https://doi.org/10.1093/elt/44.4.294

Kroll, B. (Ed.). (1990). Second language writing: Research insights for the classroom (The Cambridge Applied Linguistics Series). Cambridge University Press. https://doi.org/10.1017/CBO9781139524551

Ishtaiwa, F. F., \& Aburezeq, I. M. (2015). The impact of Google Docs on student collaboration: A UAE case study. Learning, Culture and Social Interaction, 7, 85-96. https://doi.org/10.1016/j.lcsi.2015.07.004

Lalande, J. F. (1982). Reducing composition errors: An experiment. The Modern Language Journal, 66(2), 140 149. https://doi.org/10.1111/j.1540-4781.1982.tb06973.x

Lantolf, J. P. (Ed.). (2000). Sociocultural theory and second language learning (Vol. 78, No. 4). Oxford University Press. http://old.fltrp.com/download/07041802.pdf

Lee, I. (2014). Revisiting teacher feedback in EFL writing from sociocultural perspectives. TESOL Quarterly, 48(1), 201-213. https://doi.org/10.1002/tesq.153

Lee, L. (2009). Promoting intercultural exchanges with blogs and podcasting: A study of Spanish-American telecollaboration. Computer Assisted Language Learning, 22(5), 425-443. https://doi.org/10.1080/09588220903345184

Leki, I. (1991). The preferences of ESL students for error correction in college-level writing classes. Foreign Language Annals, 24(3), 203-218. https://doi.org/10.1111/j.1944-9720.1991.tb00464.x

Miceli, T. (2006). Foreign language students' perceptions of a reflective approach to text correction. Flinders University Languages Group Online Review, 3(1), 25-36. Retrieved from http://ehlt.flinders.edu.au/deptlang/fulgor/

Montgomery, J. L., \& Baker, W. (2007). Teacher-written feedback: Student perceptions, teacher self-assessment, and actual teacher performance. Journal of Second Language Writing, 16(2), 82-99. https://doi.org/10.1016/j.jslw.2007.04.002

Nassaji, H., \& Swain, M. (2000). A Vygotskian perspective on corrective feedback in L2: The effect of random versus negotiated help on the learning of English articles. Language Awareness, 9(1), 34-51. https://doi.org/10.1080/09658410008667135

Nicol, D. J., \& Macfarlane-Dick, D. (2006). Formative assessment and self-regulated learning: A model and 
seven principles of good feedback practice. Studies in Higher Education, 31(2), 199-218. https://doi.org/10.1080/03075070600572090

Saeed, M. A., \& Ghazali, K. (2017). Asynchronous group review of EFL writing: Interactions and text revisions. Language Learning \& Technology, 21(2), 200-226. Retrieved from https://scholarspace.manoa.hawaii.edu/bitstream/10125/44618/1/21_02_saeedghazali.pdf

Semke, H. D. (1984). Effects of the red pen. Foreign Language Annals, 17(3), 195-202. https://doi.org/10.1111/j.1944-9720.1984.tb01727.x

Sheppard, K. (1992). Two feedback types: Do they make a difference? RELC Journal, 23(1), 103-110. https://doi.org/10.1177/003368829202300107

Shintani, N. (2016). The effects of computer-mediated synchronous and asynchronous direct corrective feedback on writing: A case study. Computer Assisted Language Learning, 29(3), 517-538. https://doi.org/10.1080/09588221.2014.993400

Shintani, N., \& Aubrey, S. (2016). The effectiveness of synchronous and asynchronous written corrective feedback on grammatical accuracy in a computer-mediated environment. The Modern Language Journal, 100(1), 296-319. https://doi.org/10.1111/modl.12317

Srichanyachon, N. (2012). Teacher written feedback for L2 learners' writing development. Silpakorn University Journal of Social Sciences, Humanities, and Arts, 12(1), 7-17. https://www.tci-thaijo.org/index.php/hasss/article/view/7149

Treglia, M. O. (2009). Teacher-written commentary in college writing composition: How does it impact student revisions? Composition Studies, 37(1), 67-86. https://www.jstor.org/stable/43501757

Truscott, J. (1996). The case against grammar correction in L2 writing classes. Language Learning, 46(2), 327369. https://doi.org/10.1111/j.1467-1770.1996.tb01238.x

Vygotsky, L., \& Cole, M. (1978). Mind in society: The development of higher psychological processes. Cambridge, MA: Harvard University Press.

Williams, J. (2004). Tutoring and revision: Second language writers in the writing center. Journal of Second Language Writing, 13(3), 173-201. https://doi.org/10.1016/j.jslw.2004.04.009

Wolsey, T. (2008). Efficacy of instructor feedback on written work in an online program. International Journal on E-Learning, 7(2), 311-329. Retrieved from https://www.learntechlib.org/p/23564/

Wood, D., Bruner, J. S., \& Ross, G. (1976). The role of tutoring in problem solving. Journal of Child Psychology and Psychiatry, 17(2), 89-100. https://doi.org/10.1111/j.1469-7610.1976.tb00381.x

Yang, M., Badger, R., \& Yu, Z. (2006). A comparative study of peer and teacher feedback in a Chinese EFL writing class. Journal of Second Language Writing, 15(3), 179-200. https://doi.org/10.1016/j.jslw.2006.09.004

Zamel, V. (1985). Responding to student writing. TESOL Quarterly, 19(1), 79-101. https://doi.org/10.2307/3586773

Zhang, Z. V., \& Hyland, K. (2018). Student engagement with teacher and automated feedback on L2 writing. Assessing Writing, 36, 90-102. https://doi.org/10.1016/j.asw.2018.02.004

Zhao, H. (2010). Investigating learners' use and understanding of peer and teacher feedback on writing: A comparative study in a Chinese English writing classroom. Assessing Writing, 15(1), 3-17. https://doi.org/10.1016/j.asw.2010.01.002 


\section{Appendix A}

\section{1) Samples of Teacher Feedback in Terms of Function}

\begin{tabular}{|c|c|}
\hline Type and definition & Sample \\
\hline $\begin{array}{l}\text { Question: Request for evaluation or opinions, } \\
\text { explanation, and clarification. }\end{array}$ & $\begin{array}{l}\text { T: Hi NS what do you think of this paragraph? } \\
\text { T: Hi AK why is it the best sentence as the main idea of your friend's } \\
\text { paragraph? } \\
\text { TI: Can you clarify it please RE? }\end{array}$ \\
\hline $\begin{array}{l}\text { Statement: Informing learner(s) of something, clarifying } \\
\text { or elaborating an idea, instructing them on certain points } \\
\text { in writing, and/or praising them. }\end{array}$ & $\begin{array}{l}\text { T: Hello IB you changed the direct speech into indirect speech. } \\
\text { TI: I meant you can use both structures. } \\
\text { T: Bravo AM for your corrections provided above. } \\
\text { T: Sorry ZN remember this rule: My friends and I... }\end{array}$ \\
\hline $\begin{array}{l}\text { Suggestion: Advising learner(s) what to do and/or how } \\
\text { to do something to revise writing. }\end{array}$ & $\begin{array}{l}\mathrm{T} \text { : You can move this sentence elsewhere to avoid disturbing the flow of } \\
\text { thoughts for the reader }\end{array}$ \\
\hline $\begin{array}{l}\text { Directive: Comments serving or intended by the } \\
\text { instructor to direct learner(s) to do and/or not do } \\
\text { revisions. }\end{array}$ & T: Hi RE can you look at the quotation speech and fix it! \\
\hline $\begin{array}{l}\text { Correction: A comment providing a correction or } \\
\text { highlight of learners' error(s) in writing. }\end{array}$ & $\begin{array}{l}\text { TI: come from a mother, (the) Earth. } \\
\text { T: Nowadays, I've lost all the grammar rules that I've learnt". What's } \\
\text { wrong with it? }\end{array}$ \\
\hline
\end{tabular}

\section{2) Samples of Direct and Indirect Teacher Feedback}

\begin{tabular}{ll}
\hline Type and definition & Sample \\
\hline $\begin{array}{l}\text { Direct feedback: A teacher's offer of } \\
\begin{array}{l}\text { accurate linguistic forms through inserting } \\
\text { or removing and additional explanations of }\end{array}\end{array}$ & $\begin{array}{l}\text { T: Just a few corrections between brackets: Since the creation of humans on the Earth, } \\
\text { many types of animals and plants. }\end{array}$ \\
$\begin{array}{ll}\text { such accurate linguistic forms. } \\
\begin{array}{l}\text { Indirect feedback: Any feedback indicating } \\
\text { a given error in an indirect way. }\end{array}\end{array}$ & T: Yup NS Are you sure the sentence you revised is accurate? \\
\hline
\end{tabular}

\section{3) Samples of Foci of Teacher Feedback}

\begin{tabular}{|c|c|}
\hline Type and definition & Sample \\
\hline $\begin{array}{l}\text { Content and ideas: Feedback focusing on } \\
\text { the ideas of paragraphs, supporting } \\
\text { details and relevance of content to the } \\
\text { topic. }\end{array}$ & $\begin{array}{l}\text { T: Do you think that these ideas and supporting details provide sufficient information } \\
\text { (enough) about the topic? Or do you think that more information you know needs to be } \\
\text { added? }\end{array}$ \\
\hline $\begin{array}{l}\text { Organization: Feedback focusing on the } \\
\text { flow of ideas or order of sentences in } \\
\text { writing. }\end{array}$ & T: Does the paragraph have a logical flow of ideas TI? \\
\hline $\begin{array}{l}\text { Vocabulary: Feedback focusing on the } \\
\text { accurate use of vocabulary that conveys } \\
\text { clear meaning. }\end{array}$ & $\begin{array}{l}\text { T: Look at the use of vocabulary in the two sentences you changed in the paragraph. } \\
\text { Does it accurately express the intended meanings or you need to replace some } \\
\text { vocabulary? }\end{array}$ \\
\hline $\begin{array}{l}\text { Grammar: Feedback focusing on the } \\
\text { accurate use of grammar, including } \\
\text { sentence structure in writing. }\end{array}$ & $\begin{array}{l}\text { T: Yes, SA, I agree with you that an adverb of place comes before that of time but still } \\
\text { arrived at or to? }\end{array}$ \\
\hline $\begin{array}{l}\text { Mechanics: Feedback focusing on the } \\
\text { accurate use of punctuation and spelling } \\
\text { in writing. }\end{array}$ & $\begin{array}{l}\text { T: I picked the lightest ball but unfortunately it got stuck: Can } u \text { have a closer look at } \\
\text { this and fix the punctuation errors? }\end{array}$ \\
\hline $\begin{array}{l}\text { General: Feedback that does not focus on } \\
\text { a particular area in writing. }\end{array}$ & $\begin{array}{l}\text { T: Could you please read the second drafts revised by RE and NS and point at any } \\
\text { issues/errors in them? }\end{array}$ \\
\hline
\end{tabular}

\section{Appendix B}

\section{Samples of Students' Text Revisions}

1) Content: Any text revision focusing on enhancing the content of writing by adding new ideas or elaborating ideas and deleting irrelevant ones. 
Example of an original segment of text: No matter what formal education he or she gets, having a college diploma is worth meeting the materialistic needs of post-graduates. A good example is that those who win their employers' trust, skill recognition and a good pay-raise are mostly college graduates.

Example of a revised segment of text: No matter what formal education he or she gets, having a college diploma is worth meeting the materialistic needs of post-graduates. Getting a diploma would simply enable them not only to profit from bank loans but also to take advantage of new opportunities of work thanks to college degrees. A good example is that those who win their employers' trust, skill recognition and a good pay-raise are mostly college graduates.

2) Organization: Any text revision intended to organize sentences and maintain a logical flow of ideas in writing.

Example of an original segment of text: One day, we will die and leave everything behind. This gives me a good relief from the daily shocks of this life. I need to remember always that this life is not everlasting. I also need to remember that this life would be so boring if it is only white color. When keeping this in mind, I feel more comfortable and relieved.

Example of a revised segment of text: I need to remember always that this life is not everlasting. One day, we will die and leave everything behind. This gives me a good relief from the daily shocks of this life. When keeping this in mind, I feel more comfortable and relieved. I also need to remember that this life would be so boring if it is only white color.

3) Grammar: Any text revision aimed at fixing grammatical errors, including articles, subject-verb-agreement, tenses, and sentence structures.

Example of an original segment of text: We all know that people differ, but what remain forever is our moral.

Example of a revised segment of text: We all know that people differ, but what remains forever is our moral.

4) Vocabulary: Any text revision aimed at adding new words or replacing others for the purpose of clear meaning.

Example of an original segment of text: It does not mean that you deny other's hurts for you.

Example of a revised segment of text: It does not mean that you overlook other's hurts for you.

5) Mechanics: Any text revision intended to fix errors in using punctuation and misspellings of words.

Example of an original segment of text: Although I am not a photocopy of her I will always have her inside my personality.

Example of a revised segment of text: Although I am not a photocopy of her, I will always have her inside my personality.

\section{Appendix C}

\section{1) Samples of Students' Responses in Terms of Function}

\begin{tabular}{|c|c|}
\hline Type and definition & Sample \\
\hline $\begin{array}{l}\text { Question: A question seeking suggestions, evaluation } \\
\text { and or clarifications from the teacher. }\end{array}$ & $\begin{array}{l}\text { ZN: just a suggestion T: why don't we change 'profession' into 'career'? } \\
\text { T: No problem ZN but better } 2 \text { be teaching profession. } \\
\text { TS: what do you mean T? } \\
\text { T: I meant you skipped nowadays so you change the tense that you use. } \\
\text { LR: what do you think of mine T? } \\
\text { T: Bravo and great now. }\end{array}$ \\
\hline $\begin{array}{l}\text { Suggestion: A response suggesting or providing } \\
\text { advice on how to revise. }\end{array}$ & $\begin{array}{l}\text { T: Please re-check it again and what do you suggest? } \\
\text { TS: I suggest if we have less commas, this will help in limiting the errors. }\end{array}$ \\
\hline $\begin{array}{l}\text { Evaluation: A response showing learners' opinions or } \\
\text { judgment of writing. }\end{array}$ & $\begin{array}{l}\text { T: what do you think of TI's revised paragraph now? } \\
\text { NS: HI I think it is a perfect one, so clear and comprehensive! }\end{array}$ \\
\hline $\begin{array}{l}\text { Clarification: A response showing learners' attempt to } \\
\text { explain intended meaning or idea. }\end{array}$ & $\begin{array}{l}\text { T: Hi FA what do you mean by your previous comment? } \\
\text { FA: Hi teacher I mean that losing connection like this is an evidence of the } \\
\text { negative points of online learning. }\end{array}$ \\
\hline $\begin{array}{l}\text { Explanation: A response showing learners' offer of a } \\
\text { mini lesson on a particular thing in writing. }\end{array}$ & $\begin{array}{l}\text { T: Yup SM can you explain this kind of sentence you have changed and how } \\
\text { we combine them in such a way that the reader figures out what is deleted } \\
\text { from the sentence? } \\
\text { SM: We can use such a sentence when we combine two sentences to make a }\end{array}$ \\
\hline
\end{tabular}




\begin{tabular}{|c|c|}
\hline Type and definition & Sample \\
\hline & $\begin{array}{l}\text { complex one: The children came out of the school. They were laughing and } \\
\text { playing. We can join it as the following: "The children came out of the school, } \\
\text { laughing and playing. But we should delete "were" in the second sentence and } \\
\text { put comma at the end of the first sentence. }\end{array}$ \\
\hline $\begin{array}{l}\text { Justification: A response giving a reason for a } \\
\text { particular stance of a learner. }\end{array}$ & $\begin{array}{l}\text { T: Can you tell me why not agree with NS order? } \\
\text { TS: I still don't agree with NS arrangement because this sentence seems to } \\
\text { conclude a long part of Sam's life that is why it is more likely to come before } \\
\text { the conclusion sentence rather than the weekend sentence! }\end{array}$ \\
\hline $\begin{array}{l}\text { Agreeing/disagreeing: A response showing learners' } \\
\text { agreement/disagreement about a particular point in } \\
\text { writing. }\end{array}$ & $\begin{array}{l}\text { T: Do you agree with the revision posted by TI? } \\
\text { PR: Yes, I agree with TI. } \\
\text { SA: I disagree with TI as it's okay that they happened in different places and } \\
\text { time. }\end{array}$ \\
\hline $\begin{array}{l}\text { Confirming understanding: A response indicating that } \\
\text { the learner has understood what the teacher stated or } \\
\text { wanted. }\end{array}$ & $\begin{array}{l}\text { T: Did you get me? } \\
\text { YR: Yes, teacher I got you now. }\end{array}$ \\
\hline $\begin{array}{l}\text { Issue identification: A response pointing at or } \\
\text { identifying the issue(s) in writing. }\end{array}$ & $\begin{array}{l}\text { T: Any issue in the last sentence of the revised paragraph by FA? } \\
\text { SA: I think that the last is a run-on sentence? I mean too long and needs to be } \\
\text { separated. }\end{array}$ \\
\hline $\begin{array}{l}\text { Other: Any comment by learners showing their focus } \\
\text { on other matters rather than writing. }\end{array}$ & $\begin{array}{l}\text { MD: How can I be as active as you, despite the fact that I'm connected from } \\
\text { mobile? }\end{array}$ \\
\hline
\end{tabular}

\section{2). Samples of Foci of Students' Responses}

\begin{tabular}{|c|c|}
\hline Type and definition & Sample \\
\hline $\begin{array}{l}\text { Content and ideas: Any response focusing on the ideas } \\
\text { of paragraphs, supporting details, and relevance of } \\
\text { content to the topic. }\end{array}$ & $\begin{array}{l}\text { T: Hi ZN what do you think of the content and ideas of the revised paragraph } \\
\text { by SA? } \\
\text { ZN: About the content of the paragraph, I think it reflects the topic and gives } \\
\text { a clear idea about it. }\end{array}$ \\
\hline $\begin{array}{l}\text { Organization: Any response focusing on the flow of } \\
\text { ideas or order of sentences in writing. }\end{array}$ & $\begin{array}{l}\text { T: What about the new order of sentences in your revised paragraph? } \\
\text { TS: I put it this order to make it chronologically reasonable: as a kid, a } \\
\text { primary school student, a teenager and then a university student. }\end{array}$ \\
\hline $\begin{array}{l}\text { Vocabulary: Any response focusing on the accurate use } \\
\text { of vocabulary that conveys clear meaning. }\end{array}$ & $\begin{array}{l}\text { T: Bravo NA for your good comments and awareness of mistakes, so look at } \\
\text { FA's paragraph please if any more mistakes. } \\
\text { NA: She was great; I just found some words like gathered and stuff. They } \\
\text { need to be replaced I guess to be clear! }\end{array}$ \\
\hline $\begin{array}{l}\text { Grammar: Any response focusing on the accurate use } \\
\text { of grammar, including sentence structure in writing. }\end{array}$ & $\begin{array}{l}\text { T: Great and TS and let us see your comment on the revision done by LR. } \\
\text { TS: The use of the past tense and the past participle: told them-what had } \\
\text { happened. }\end{array}$ \\
\hline $\begin{array}{l}\text { Mechanics: Any response focusing on the accurate use } \\
\text { of punctuation and spelling in writing. }\end{array}$ & $\begin{array}{l}\text { T: What about the spelling? } \\
\text { RE: nothing wrong dear } \mathrm{u} \text { just misspelling two }\end{array}$ \\
\hline Procedure and social task: & $\begin{array}{l}\text { YR: I think I have a problem in receiving your comments. } \\
\text { SA: Have a nice day sister } \wedge\end{array}$ \\
\hline
\end{tabular}

\section{Copyrights}

Copyright for this article is retained by the author, with first publication rights granted to the journal.

This is an open-access article distributed under the terms and conditions of the Creative Commons Attribution license (http://creativecommons.org/licenses/by/4.0/). 